\title{
Effects of COVID-19 Pandemic on Diagnosis-treatment Process in Breast Cancer Patients Treated with Neoadjuvant Chemotherapy
}

\author{
Neoadjuvan Kemoterapi Alan Meme Kanseri Hastalarında COVID-19 Pandemisinin Tanı ve \\ Tedavi Sürecine Etkileri
}

\author{
(D) Eyyüp ÇAVDAR, (D) Yakup IRIAĞAÇ, (D) Kubilay KARABOYUN, D Okan AVCI, (D) Erdoğan Selçuk ŞEBER \\ Tekirdağ Namık Kemal University Faculty of Medicine, Department of Medical Oncology, Tekirdağ, Turkey
}

\begin{abstract}
Aim: In this study, we investigated the effect of pandemic on the diagnosis-treatment process in breast cancer patients receiving neoadjuvant chemotherapy.

Materials and Methods: The clinicopathological characteristics of the total patients who received neoadjuvant chemotherapy for one year during the Coronavirus disease-2019 (COVID-19) pandemic period and one year before the pandemic were compared. A total of 92 patients were analyzed retrospectively.

Results: The clinicopathological features in the pandemic and prepandemic periods were found to be similar. While the number of patients was $26(28.3 \%)$ during the pandemic period, it was $66(71.7 \%)$ in the prepandemic period. Pathology reporting time, chemotherapy administration time, preoperative preparation time and overall time from diagnosis to treatment were similar $(p=0.305, p=0.171, p=0.104, p=0.061, r e s p e c t i v e l y)$. Magnetic resonance reporting time was shorter during the pandemic period $(p=0.005)$.

Conclusion: The diagnosis and treatment times of breast cancer in patients receiving neoadjuvant chemotherapy in the pandemic period are similar to those in the pre-pandemic period. Nevertheless, decision should be made on a patient-specific basis considering COVID-19 infection risk.
\end{abstract}

Keywords: COVID-19, pandemic, coronavirus, breast cancer, neoadjuvant

ÖZ

Amaç: Bu çalışmamızda neoadjuvan kemoterapi alan meme kanseri hastalarında pandeminin tanı-tedavi sürecine etkisini araştırdık.

Gereç ve Yöntem: Koronavirüs hastalığı-2019 (COVID-19) pandemisi dönemindeki bir yıl ile pandemi öncesindeki 1 yılda neoadjuvan kemoterapi alan hastaların klinikopatolojik özellikleri ile tanıdan operasyona kadar olan aşamaların süreleri karşılaştırıldı. Toplam 92 hasta retrospektif olarak analiz edildi.

Bulgular: Pandemi ve pandemi öncesi (prepandemik) dönemdeki hastaların klinikopatolojik özellikleri benzer bulundu. Pandemi dönemindeki hasta sayısı $26(\% 28,3)$ iken pandemi öncesi dönemde $66(\% 71,7)$ idi. Tanı-tedavi sürelerinden patoloji raporlanma süresi, kemoterapi uygulanma süresi ve preoperatif hazırlık dönemi ve total süre iki dönem arasında benzerdi (sırasıyla; $p=0,305, p=0,171, p=0,104, p=0,061$ ). Manyetik rezonans raporlanma süresi pandemi döneminde daha kısa saptandı $(p=0,005)$.

Sonuç: Neoadjuvan kemoterapi alan hastalarda meme kanserinin tanı ve tedavi süreleri pandemi döneminde, pandemi öncesi dönemle benzerdir. Yine de COVID-19 enfeksiyon riski düşünülerek hasta özelinde karar verilmelidir.

Anahtar Kelimeler: COVID-19, pandemi, koronavirüs, meme kanseri, neoadjuvan

Address for Correspondence: Eyyüp ÇAVDAR MD, Tekirdağ Namık Kemal University Faculty of Medicine, Department of Medical Oncology, Tekirdağ, Turkey Phone: +90 5515981405 E-mail: eyyupcavdar@hotmail.com ORCID ID: orcid.org/0000-0001-5885-3047

Received: 20.04.2021 Accepted: 25.07.2021

๑Copyright 2021 by the Tekirdağ Namık Kemal University Faculty of Medicine / Namık Kemal Medical Journal published by Galenos Publishing House. 


\section{Introduction}

The Severe acute respiratory syndrome-Coronavirus-2 epidemic, which started in Wuhan, China in 2019, was declared as a COVID-19 pandemic by the World Health Organization (WHO) on March 11, 2020'. According to the latest WHO data, more than 125 million people were infected with COVID-19 and over 2.7 million people died ${ }^{2}$. Serious disruptions occurred in health systems that came to the point of collapse, and "stay at home" orders, travel restrictions, social isolation rules and lockdowns were implemented in many countries around the world ${ }^{3,4}$. In our country, the first case of COVID-19, which affected the whole World, was seen on March 11, 20205. The first major measures for COVID-19 in Turkey were taken on March 21, 2020, for the purpose of precaution after rapid increase in cases $^{6}$. Although the bans have been eased as of March 2021, lockdowns still continue in our country.

The coronavirus pandemic has led to sudden and complex changes in healthcare, including primary care ${ }^{7,8}$. Due to this situation, high-risk patients in terms of COVID-19 were determined in order to minimize disruptions, and this was led by patients diagnosed with cancer ${ }^{9,10}$. In the analysis performed by Saini et al. ${ }^{11}$, the mortality rate in cancer patients was found to be $25.6 \%$. As of 2021, new treatment, diagnosis and screening guidelines have been published in order to minimize the risk for breast cancer patients, which is the most common cancer worldwide $\mathrm{e}^{8,12-14}$.

With the pandemic, the normal working orders of the units except for the emergency health services were suspended, and oncology clinics were also affected. In this study, we examined the one year before the COVID-19 bans began to be implemented in our country, and one year in which COVID-19 measures and restrictions were applied, in breast cancer patients who were given neoadjuvant treatment. We aimed to investigate the effect of the COVID-19 pandemic on the clinicopathological changes of the patients diagnosed between two years, during the reporting period of radiology and pathology, during the chemotherapy process, and during the diagnosis-surgery periods. We aim to contribute to the literature on the effect of neoadjuvant chemotherapy applications and breast cancer diagnosis-treatment process during the pandemic period.

\section{MATERIALS AND METHODS}

The research was a retrospective comparative study and was conducted in the medical oncology department of the university hospital. The study was approved by the Ethics Committee of Tekirdağ Namık Kemal University Faculty of Medicine on 30.03.2021 (issue no: 2021.76.03.16) and by the T.R. Ministry of Health Scientific Research Platform. The research was conducted in accordance with the Declaration of Helsinki.
In our study, the data of patients, who were diagnosed with breast cancer in our hospital between March 21, 2019 and March 21, 2021, received neoadjuvant chemotherapy and were operated afterwards, were analyzed retrospectively. All of the patients included in the study consisted of patients who received either docetaxel $\left(75 \mathrm{mg} / \mathrm{m}^{2}\right)$ every three weeks for four cycles or paclitaxel $\left(80 \mathrm{mg} / \mathrm{m}^{2}\right)$ once a week for 12 cycles after four cycles of cyclophosphamide + epirubicin. Fluorine-18fluorodeoxyglucose positron emission tomography/computed tomography and magnetic resonance (MR) imaging performed before treatment were used for staging the patients.

Patients were put into two groups. Those diagnosed before March 21, 2020, when the COVID-19 restriction began to be implemented in our country, were evaluated as the prepandemic period (March 21, 2019-March 21, 2020) and those diagnosed after this date were evaluated as the pandemic period (March 21, 2020-March 21, 2021). In order to ensure complete reliability in the analysis of the data, patients who completed the entire period from diagnosis to operation in their own group were included in the study. Those with time deviations from the specified dates and groups were excluded from the study.

Pathology reporting time was accepted as the time between taking the tru-cut biopsy and reporting it, MR reporting time as the time from MR scan date to reporting for staging before neoadjuvant chemotherapy, chemotherapy time as the time between the first chemotherapy and the last chemotherapy (those who received weekly paclitaxel chemotherapy were evaluated as four cycles and the first day of the fourth cycle was taken as the end of chemotherapy). And the preoperative preparation time after chemotherapy was counted from this last chemotherapy date to the operation. As the total time, the time from the first biopsy date to the surgery was taken.

Clinicopathological and demographic characteristics, radiological examination and reporting dates, pathology acceptance and approval dates, chemotherapy durations and operation dates of the patients before the start of treatment were recorded from the hospital archive.

\section{Statistical Analysis}

Statistical Package for the Social Sciences for Windows 26.0 package program was used for statistical analysis of the data. Categorical measurements were summarized as numbers and percentages, and continuous measurements as mean and standard deviation. The comparison of categorical measurements between groups was also done with the chisquare test. The Fisher's exact test was used when cells with frequencies less than five were present in the crosstab analysis. The normal distribution of the data was evaluated with the Kolmogorov-Smirnov test. Non-parametric tests 
(Mann-Whitney U) were used to compare continuous variables that were not normally distributed, and parametric tests (independent sample t-test) were used to compare continuous variables that were normally distributed. The statistical significance limit " $p$ " was accepted as 0.05 .

\section{RESULTS}

A total of 102 patients' records were reached between March 21, 2019 and March 21, 2021. The examinations of 10 patients started in the pre-pandemic period but were extended to the pandemic period, and they were excluded from the study. 92 patients who met the criteria were included in the study. Of the patients, $26(28.3 \%)$ were in the pandemic period, and 66 $(71.7 \%)$ were in the pre-pandemic period. The median age was $47.14 \pm 10.48$ (age range $24-79$ ) years. All of the patients were female. It was determined that $2(7.77 \%)$ of the patients in the pandemic group included in the study had COVID-19 infection within the specified period. When the clinicopathological features of pre-pandemic and pandemic patients were compared, no significant difference was found between the groups. The results were as in Table 1.

The mean total time from the first diagnosis to the operation of the patients included in the study was $220.91 \pm 28.85$ (range 121-362) days. MR reporting time was 16.14 \pm 11.19 (range 2-51) days, pathology reporting time was $15 \pm 8.01$ (range 6-36) days, chemotherapy time was $152.26 \pm 10.28$ (range 131-189) days, and preoperative preparation time after chemotherapy was $35.94 \pm 9.02$ (range was 20-61) days. When the prepandemic and pandemic periods were compared, a significant difference was found in the MR reporting period $(p=0.005)$, and there was no statistically significant difference between the other periods. The results of the comparison of the two groups were presented in Table 2.

\section{DISCUSSION}

In our study, we aimed to investigate the effect of the COVID-19 pandemic, from breast cancer diagnosis to treatment, in breast cancer patients receiving neoadjuvant chemotherapy. It was planned to compare the year before the beginning of the restrictions on the COVID-19 pandemic in our country with the year in the pandemic process, and 92 patients who met the criteria were analyzed retrospectively. In the first year of the pandemic, the number of patients receiving neoadjuvant chemotherapy was found to have decreased significantly compared to the pre-pandemic period. In our study, there was no difference between the clinicopathological features of the patients admitted during the pre-pandemic period and the pandemic period. While there was a significant decrease in MR reporting time, there was no difference in the comparison of the other diagnosis-treatment stages.
In our study, a significant decrease was observed in the number of breast cancer patients receiving neoadjuvant chemotherapy in the pandemic period compared to the pre-pandemic period. The decrease in the number of patients might have resulted from the decrease in hospital access due to restrictions or patient's hesitation due to the pandemic ${ }^{15-17}$. The detection of a correlation between anxiety and female gender in studies on the COVID-19 pandemic conducted in our country and abroad suggests that patient's hesitation plays an important role in the decrease in the number of patients in addition to pandemic restrictions ${ }^{18-20}$.

Studies reporting that there are similar reductions and disruptions in the diagnoses of new diseases in 2020, not only in our country but all over the world, are consistent with our study ${ }^{16,21-23}$.

According to the American Society of Clinical Oncology and the European Society of Medical Oncology, one of the neoadjuvant chemotherapy regimens recommended for the COVID-19 pandemic is AC-T ( \pm anti-HER-2 therapy), that is, the combination of cyclophosphamide and anthracycline. This regimen is the chemotherapy regimen that we included in our study and that is frequently used in our center. While delaying surgery is not recommended in the triple-negative and HER-2-positive groups in the guidelines, it is suggested that 6-12 months of neoadjuvant therapy may be continued in hormone-positive/HER-2-negative subtypes, depending on the risk status ${ }^{24}$. In our study, the durations in accordance with the guidelines were considered and there was no difference in chemotherapy duration between the pre-pandemic period and the pandemic period $(p=0.171)$.

In our study, a significantly shorter MR reporting time was observed during the pandemic period compared to the prepandemic period $(p=0.005)$. This may be a reflection of the decrease in the number of patient admissions to the workload. However, the similarity of the total times from diagnosis to operation may be due to the prolongation of the chemotherapy duration and preoperative preparation time, which did not reach statistical significance but showed a numerical increase. In addition, the delay in the treatment of 2 patients due to the diagnosis of COVID-19 during the pandemic period also contributed to this situation. However, the times determined in our study are within the times recommended in the guidelines ${ }^{25,26}$.

In the current COVID-19 pandemic period, while healthcare institutions are trying to provide the highest level and complete service in diseases such as cancer, for which the treatment and diagnosis process is unlikely to be delayed, on the other hand, they have to make decisions according to the conditions of the day, taking into account the health of the employees and the patient. Recommendations about chemotherapy 


\section{Table 1. Clinicopathological characteristics of the patients and their distribution according to the pandemic period}

\begin{tabular}{|c|c|c|c|c|}
\hline & Total & Pre-pandemic period $(n=66)$ & Pandemic period $(n=26)$ & $\mathrm{p}$ \\
\hline \multicolumn{5}{|l|}{ Age } \\
\hline$<40$ (young adult) & $26(28.3 \%)$ & $20(76.9 \%)$ & $6(23.1 \%)$ & \multirow{2}{*}{0.488} \\
\hline$\geq 40$ & $66(71.7 \%)$ & $46(69.7 \%)$ & $20(30.3 \%)$ & \\
\hline \multicolumn{5}{|l|}{ Menopausal status } \\
\hline Premenopause & $38(41.3 \%)$ & $27(71.1 \%)$ & $11(28.9 \%)$ & \multirow{2}{*}{0.902} \\
\hline Postmenopause & 54 (58.7\%) & 39 (72.2\%) & 15 (27.8\%) & \\
\hline \multicolumn{5}{|l|}{ Histological type } \\
\hline Ductal type & $73(79.3 \%)$ & $52(71.2 \%)$ & $21(28.8 \%)$ & \multirow{2}{*}{0.832} \\
\hline Others & $19(20.7 \%)$ & $14(73.7 \%)$ & $5(26.3 \%)$ & \\
\hline \multicolumn{5}{|l|}{ Progesterone receptor } \\
\hline Negative & $42(45.7 \%)$ & $29(69.0 \%)$ & $13(31.0 \%)$ & \multirow{2}{*}{0.599} \\
\hline Positive & 50 (54.3\%) & $37(74.0 \%)$ & 13 (26.0\%) & \\
\hline \multicolumn{5}{|l|}{ Estrogen receptor } \\
\hline Negative & $28(30.4 \%)$ & $18(64.3 \%)$ & $10(35.7 \%)$ & \multirow{2}{*}{0.293} \\
\hline Positive & $64(69.6 \%)$ & $48(75.0 \%)$ & $16(25.0 \%)$ & \\
\hline \multicolumn{5}{|l|}{ HER-2 receptor } \\
\hline Negative & $55(59.8 \%)$ & $39(70.9 \%)$ & $16(29.1 \%)$ & \multirow{2}{*}{0.829} \\
\hline Positive & $37(40.2 \%)$ & 27 (73.0\%) & $10(27.0 \%)$ & \\
\hline \multicolumn{5}{|l|}{ Grade } \\
\hline Grade 1 & $4(4.3 \%)$ & 3 (75.0\%) & $1(25.0 \%)$ & \multirow{3}{*}{0.479} \\
\hline Grade 2 & $51(55.4 \%)$ & $34(66.7 \%)$ & $17(33.3 \%)$ & \\
\hline Grade 3 & 37 (40.2\%) & 29 (78.4\%) & 8 (21.6\%) & \\
\hline \multicolumn{5}{|l|}{ Clinical T stage } \\
\hline T1 & $24(26.1 \%)$ & $16(66.7 \%)$ & 8 (33.3\%) & \multirow{3}{*}{0.777} \\
\hline T2 & $59(64.1 \%)$ & $43(72.9 .8 \%)$ & $16(27.1 \%)$ & \\
\hline T3-T4 & $9(9.8 \%)$ & $7(77.8 \%)$ & $2(22.2 \%)$ & \\
\hline \multicolumn{5}{|l|}{ Clinical N stage } \\
\hline No & $30(32.6 \%)$ & 26 (86.7\%) & $4(13.3 \%)$ & \multirow{4}{*}{0.099} \\
\hline N1 & $35(38.0 \%)$ & $23(65.7 \%)$ & $12(34.3 \%)$ & \\
\hline N2 & $17(18.5 \%)$ & $12(70.6 \%)$ & $5(29.4 \%)$ & \\
\hline N3 & $10(10.9 \%)$ & $5(50.0 \%)$ & $5(50.0 \%)$ & \\
\hline \multicolumn{5}{|l|}{ Status of receiving RT } \\
\hline Received & $86(93.5 \%)$ & $61(70.9 \%)$ & $25(29.1 \%)$ & \multirow{2}{*}{0.672} \\
\hline Not received & $6(6.5 \%)$ & $5(83.3 \%)$ & $1(16.7 \%)$ & \\
\hline \multicolumn{5}{|l|}{ Surgery type } \\
\hline Breast protective & 75 (81.5\%) & $51(68.0 \%)$ & $24(32.0 \%)$ & \multirow{2}{*}{0.094} \\
\hline Others & $17(18.5 \%)$ & $12(88.2 \%)$ & $2(11.8 \%)$ & \\
\hline \multicolumn{5}{|l|}{ Chemotherapy type } \\
\hline CE+ weekly paclitaxel & $38(41.3 \%)$ & $29(76.3 \%)$ & $9(23.7 \%)$ & \multirow{2}{*}{0.413} \\
\hline ( \pm HER-2 blockade) & $54(58.7 \%)$ & $37(68.5 \%)$ & $17(31.5 \%)$ & \\
\hline
\end{tabular}


Table 2. Comparison of the characteristics of the time spent in the diagnosis and treatment stages according to the pandemic periods

\begin{tabular}{|c|c|c|c|c|c|}
\hline & \multicolumn{2}{|c|}{ Pre-pandemic period $(n=66)$} & \multicolumn{2}{|c|}{ Pandemic period $(n=26)$} & \multirow[b]{2}{*}{ p } \\
\hline & Mean \pm SD & Median & Mean \pm SD & Median & \\
\hline Pathology reporting time & $15.71 \pm 8.59$ & 13.0 & $13.19 \pm 6.05$ & 10.5 & 0.305 \\
\hline MR reporting time & $18.30 \pm 11.8$ & 18.0 & $10.65 \pm 7.05$ & 8.0 & 0.005 \\
\hline Chemotherapy duration & $150.48 \pm 8.12$ & 149.0 & $156.76 \pm 13.55$ & 150.5 & 0.171 \\
\hline $\begin{array}{l}\text { Preop preparation time after } \\
\text { chemotherapy }\end{array}$ & $34.98 \pm 9.22$ & 34.50 & $38.38 \pm 8.17$ & 37.5 & 0.104 \\
\hline Total time & $218.40 \pm 31.37$ & 217.0 & $227.26 \pm 20.33$ & 222.0 & 0.061 \\
\hline \multicolumn{5}{|c|}{ Statistically significant $p$ values are shown in bold font. } & \\
\hline
\end{tabular}

regimens, patient follow-up, surgical preparation times and even operation options have been reported in guidelines and previous studies $8,24,25$. However, there are also publications stating that the same treatment cannot be applied to everyone during the pandemic period ${ }^{27}$.

\section{Study Limitations}

The limitation of our study is that it was performed in a single center, the number of cases was limited, and it was retrospective. Imaging, reporting and other investigated times may differ in centers other than our hospital. This is another limiting factor of our study. Although studies examining the effects of the COVID-19 pandemic on diagnosis-treatment stages in breast cancer are limited in the literature, our study, which was conducted using the same center data, is important in that it is the first in this regard.

\section{CONCLUSION}

In conclusion, in our study, we have found that, in the pandemic period, the current diagnosis and treatment stages can be applied in the same way as in the pre-pandemic period for patients, and that disruptions are acceptable periods of time. However, considering our patients who caught COVID-19 during treatment, the risk of COVID-19 infection should be taken into account when making a treatment decision and cooperation with the patient should be made. Since the duration and continuity of the COVID-19 pandemic are unknown, multicenter, prospective studies with large numbers of patients are needed for effective treatment evaluations.

\section{Ethics}

Ethics Committee Approval: The study was approved by the Ethics Committee of Tekirdağ Namık Kemal University Faculty of Medicine on 30.03.2021 (issue no: 2021.76.03.16) and by the T.R. Ministry of Health Scientific Research Platform.

Informed Consent: Retrospective study.
Peer-review: Externally peer-reviewed.

\section{Authorship Contributions}

Concept: E.Ç., K.K., O.A., E.S.Ş., Design: E.Ç., Y.I., O.A., E.S.Ş., Data Collection or Processing: E.Ç., Y.I., K.K., O.A., E.S.Ş., Analysis or Interpretation: E.Ç., Y.I., K.K., O.A., E.S.Ş., Literature Search: E.Ç., O.A., E.S.Ş., Writing: E.Ç.

Conflict of Interest: No conflict of interest was declared by the authors.

Financial Disclosure: The authors declared that this study received no financial support.

\section{References}

1. WHO. Director-General's opening remarks at the media briefing on COVID-19. Erişim tarihi: 11 Mart 2020. Erişim adresi: https://www.who. int/director-general/speeches/detail/who-director-general-s-openingremarks-at-the-media-briefing-on-covid-19---11-march-2020

2. WHO. WHO Coronavirus Disease (COVID-19) Dashboard. 2021. Erişim adresi: https://web.archive.org/web/20210101171129/https://covid19.who.int

3. Gostin LO, Wiley LF. Governmental Public Health Powers During the COVID-19 Pandemic: Stay-at-home Orders, Business Closures, and Travel Restrictions. JAMA. 2020;323:2137-8.

4. Yezli S, Khan A. COVID-19 social distancing in the Kingdom of Saudi Arabia: Bold measures in the face of political, economic, social and religious challenges. Travel Med Infect Dis. 2020;37:101692.

5. T.C. Sağlık Bakanlığı. COVID-19 Bilgilendirme Platformu. 2021. Erişim adresi: https://covid19.saglik.gov.tr/TR-66935/genel-koronavirus-tablosu.html

6. T.C. İçişleri Bakanlığı. 65 Yaş ve Üstü ile Kronik Rahatsızlığı Olanlara Sokağa Çıkma Yasağı Genelgesi. 2021. Erişim adresi: https://www.icisleri.gov. tr/65-yas-ve-ustu-ile-kronik-rahatsizligi-olanlara-sokaga-cikma-yasagigenelgesi

7. Chabner BA. Taking the Longer View of COVID-19. Oncologist. 2020;25:455-

8. Manoj Gowda S, Kabeer KK, Jafferbhoy S, Marla S, Soumian S, Misra V, et al. Breast Cancer Management Guidelines During COVID-19 Pandemic. Indian J Surg. 2020:1-8.

9. Liang W, Guan W, Chen R, Wang W, Li J, Xu K, et al. Cancer patients in SARS-CoV-2 infection: a nationwide analysis in China. Lancet Oncol. 2020;21:335-7.

10. Ismaili N. COVID-19 Recommendations for Patients with Cancer: The postCOVID-19 Era. SN Compr Clin Med. 2020:1-6. 
11. Saini KS, Tagliamento $M$, Lambertini $M$, McNally $R$, Romano $M$, Leone $M$, et al. Mortality in patients with cancer and coronavirus disease 2019: A systematic review and pooled analysis of 52 studies. Eur J Cancer. 2020;139:43-50.

12. Society of Surgical Oncology. Resource for Management Options of Breast Cancer During COVID-19. 2020. Erişim adresi: https://www.surgonc.org/wpcontent/uploads/2020/03/Breast-Resource-during-COVID-19-3.23.20.pdf

13. Colombo I, Zaccarelli E, Del Grande M, Tomao F, Multinu F, Betella I, et al. ESMO management and treatment adapted recommendations in the COVID-19 era: gynaecological malignancies. ESMO Open. 2020;5(Suppl 3):e000827.

14. Sezer A, Cicin I, Karadeniz Çakmak G, Özkan Gürdal S, Başaran G, Oyan $B$, et al. Turkish national consensus on breast cancer management during temporary state of emergency due to COVID-19 outbreak. Turk J Surg. 2020;36:147-63.

15. Daraï E, Mathelin C, Gligorov J. Breast Cancer Management during the COVID 19 Pandemic: French Guidelines. Eur J Breast Health. 2020;16:160-1.

16. Siegel RL, Miller KD, Fuchs HE, Jemal A. Cancer Statistics, 2021. CA Cancer J Clin. 2021;71:7-33.

17. Oseran AS, Nash D, Kim C, Moisuk S, Lai PY, Pyhtila J, et al. Changes in hospital admissions for urgent conditions during COVID-19 pandemic. Am J Manag Care. 2020;26:327-8.

18. Özdin S, Bayrak Özdin Ş. Levels and predictors of anxiety, depression and health anxiety during COVID-19 pandemic in Turkish society: The importance of gender. Int J Soc Psychiatry. 2020;66:504-11.

19. Pappa S, Ntella V, Giannakas T, Giannakoulis VG, Papoutsi E, Katsaounou P. Prevalence of depression, anxiety, and insomnia among healthcare workers during the COVID-19 pandemic: A systematic review and meta-analysis. Brain Behav Immun. 2020;88:901-7.
20. Karacin C, Bilgetekin I, B Basal F, Oksuzoglu OB. How does COVID-19 fear and anxiety affect chemotherapy adherence in patients with cancer. Future Oncol. 2020;16:2283-93.

21. Hartnett KP, Kite-Powell A, DeVies J, Coletta MA, Boehmer TK, Adjemian J, et al. Impact of the COVID-19 Pandemic on Emergency Department Visits - United States, January 1, 2019-May 30, 2020. MMWR Morb Mortal Wkly Rep. 2020;69:699-704.

22. Gülşen I. Covid-19 pandemisinin kronik viral hepatit hizmetleri üzerinde etkisi. Kesit Akad Derg. 2020;6:685-93.

23. Roberton $T$, Carter ED, Chou VB, Stegmuller AR, Jackson BD, Tam $Y$, et al. Early estimates of the indirect effects of the COVID-19 pandemic on maternal and child mortality in low-income and middle-income countries: a modelling study. Lancet Glob Health. 2020;8:e901-e8.

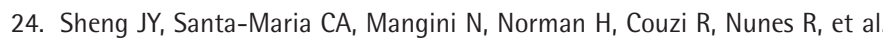
Management of Breast Cancer During the COVID-19 Pandemic: A Stageand Subtype-Specific Approach. JCO Oncol Pract. 2020;16:665-74.

25. Sanford RA, Lei $X$, Barcenas $C H$, Mittendorf EA, Caudle AS, Valero V, et al. Impact of Time from Completion of Neoadjuvant Chemotherapy to Surgery on Survival Outcomes in Breast Cancer Patients. Ann Surg Oncol. 2016;23:1515-21.

26. Müller C, Juhasz-Böss I, Schmidt G, Jungmann P, Solomayer EF, Breitbach $\mathrm{GP}$, et al. Factors influencing the time to surgery after neoadjuvant chemotherapy in breast cancer patients. Arch Gynecol Obstet. 2020;301:1055-9.

27. Krishnamurthy A. Advances in surgery in 2020: The impact of the COVID-19 pandemic on cancer surgeries and cancer care - a brief overview. Indian J Cancer. 2021;58:38-40. 